\title{
ロボット支援腹腔鏡下子宮全摘術の導入と周術期アウトカムの検討
}

\author{
滋賀県立総合病院 婦人科 ${ }^{11}$ 、南草津健診センター ${ }^{2}$
}

澤山咲輝 ${ }^{1)}$ 、村上隆介 ${ }^{1)}$ 、多賀悠希子 ${ }^{1)}$ 、川口雄亮 ${ }^{1)}$ 、矢内晶太 ${ }^{1)}$ 、野々垣比路史 ${ }^{1,2)}$

\section{Perioperative outcomes of the introduction of robot-assisted laparoscopic hysterectomy}

\author{
Saki Sawayama ${ }^{1)}$, Ryusuke Murakami ${ }^{1)}$, Yukiko Taga ${ }^{1)}$, \\ Yusuke Kawaguchi ${ }^{1}$, Akihiro Yanai ${ }^{1}$, Hirofumi Nonogaki ${ }^{1,2)}$ \\ Department of Gynecology, Shiga General Hospital ${ }^{1)}$, Minamikusatsu Health Examination Center ${ }^{2)}$
}

\begin{abstract}
Objective: Perioperative outcomes in the first year of introducing robot-assisted hysterectomy (RAH) using the daVinci $\mathrm{Xi}$ surgical system were evaluated based on comparisons with conventional laparoscopic hysterectomy (CLH) for simple hysterectomies performed during the same period.

Methods: This was a retrospective study involving comparisons between 38 cases of RAH from June 2019 to April 2020 and 28 cases of CLH from August 2018 to April 2020. All cases involved simple hysterectomies performed by 4 doctors ( 1 endoscopic technique-certified medical doctor and 3 doctors with less than 10 years of experience).

Results: The characteristics of patients who underwent RAH and CLH were as follows, respectively: age, 47 vs 49 years (mean, $\mathrm{p}=0.62$ ); body mass index, $23.4 \mathrm{vs} 22.9 \mathrm{~kg} / \mathrm{m}^{2}$ (mean, $\mathrm{p}=0.57$ ); uterine weight, 152 and $175 \mathrm{~g}$ (median, $\mathrm{p}=0.39$ ); manipulator use, $28(73 \%)$ and $21(75 \%)$ cases (frequency, $\mathrm{p}=0.90)$; and $0 / 4$ cases with endometriotic adhesions with Douglas fossa closure, 0 and 4 cases (frequency, $\mathrm{p}=0.028$ ). The total operation time (from skin incision to skin closure) was significantly shorter in RAH cases (mean difference, 29 minutes; $\mathrm{p}=0.048$ ) than in CLH cases. There was no significant difference between the two groups in terms of blood loss and perioperative complications.

Conclusion: We safely introduced RAH by selecting appropriate cases in advance. In the future, it is necessary to study robot-assisted surgery so that it can be safely introduced in patients with large uterine weights and endometriotic adhesions.
\end{abstract}

Keywords: robot-assisted laparoscopic hysterectomy, laparoscopic hysterectomy

\section{緒言}

ここ数年で婦人科領域における Minimally invasive surgery（以下MIS）は発展、普及した。 1988年に世界で初めて腹腔鏡下子宮全摘術が行わ れてから ${ }^{1)}$ 約15年後の 2005 年に米国で婦人科領域 でのロボット支援下手術が承認された ${ }^{2)}$ 。本邦で は2018年 4 月の診療報酬改定で、良性腫瘍に対す るロボット支援下子宮全摘術及び初期の子宮体癌 に対するロボット支援下子宮悪性腫瘍手術が保険 適応となった。ロボット支援下手術の導入や指導
については関係学会がプロクター制度を準備して いるが、各施設で試行錯誤の段階ではあると思わ れ、安全性の担保がまずは肝要である。

ロボット支援下手術と腹腔鏡下手術を比較した ランダム化比較試験は幾つか存在し、周術期アウ トカムは施設や術者などの背景により異なる結 果 ${ }^{2-5)}$ であったが、ロボット支援下手術はlearning curveが早いという特徴がある6,7)。また、実際に トロッカー留置やドッキング、清潔術野での鉗子 交換、出血時の補助的操作、緊急開腹時の対応な どは助手が行うため、チームでの育成は手術の質 
を高めると報告される ${ }^{8)}$ 。

当科では2019年6月にda Vinci Xi ${ }^{\circledR}$ Surgical Systemを導入し、同月からロボット支援下手術 が運用開始となり、卒後 10 年以下の若手医師を中 心とした婦人科チームで、積極的にロボット支援 下手術の導入を行ってきた。本検討では円滑な導 入のために行った経験を振り返り、安全性につい て検証するため、同一術者 4 名が実施した単純子 宮全摘術におけるロボット支援下手術と腹腔鏡下 手術を後方視的に検討し、手術時間や出血量、合 併症の有無などの周術期アウトカムを明らかにし た。

\section{対象と方法}

当院では2019年 6 月にda Vinci Xi ${ }^{\circledR}$ Surgical System (Intuitive Surgical, Inc., Sunnyvale, CA, USA）を導入し、婦人科、外科、泌尿器科、呼 吸器外科でのロボット支援下手術がそれぞれ運用 開始となった。2019年 6 月〜2020年 4 月に 4 名の 婦人科術者が施行したロボット支援下単純子宮全 摘術38例と、2018年 8 月～2020年 4 月に同一術者 4 名が施行した腹腔鏡下単純子宮全摘術28例を後 方視的に比較検討した。また本研究は当院の倫理 委員会の承認を得ている。（承認番号：2020083101)

\section{症例の選定方法}

当科では単純子宮全摘術のMISの適応は子宮底 部が岬角以下のサイズとしている。該当する症例 に対しては術前のインフォームドコンセントとし て、開腹手術、腹腔鏡下手術、ロボット支援下手 術について、それぞれの手術のメリット・デメリ ットを事前に説明し、最終的には患者の希望で術 式を決定している。ただし、内膜症性の強い癒着 が予想される症例についてはロボット支援下手術 よりも腹腔鏡下手術が慣れていることを説明して おり、患者はいずれも腹腔鏡下手術を選択してい る。

\section{導入時期の術者について}

ロボット支援機器は全例da Vinci $\mathrm{Xi}^{\circledR}$ Surgical Systemで行い、Intuitive Surgical社のcertificate を取得した 4 名が執刀、助手を行った。導入初期 は、すでにcertificateを取得し前任施設でのロボ ット手術経験があり日本産科婦人科内視鏡学会認 定腹腔鏡技術認定医（以下、技術認定医）を取得 している医師が 1 名で開始した。技術認定医取得
前の卒後10年目以下の若手医師 3 名が、日本産科 婦人科学会の推奨するロボット支援下手術に関す る指針の要件を満たし、最初の 3 か月で全員が certificateを取得した。若手医師が執刀の際には テレストレーション機能などを用いて技術認定医 の指導のもと手術を実施した。

今回検討した腹腔鏡下手術の症例の時期はロボ ット支援下手術導入前からにはなるが、腹腔鏡下 手術はロボット支援下手術と同一術者の 4 名が施 行した症例を対象とした。経験年数はそれぞれ医 師 17 年目 (指導医)、 9 年目 (若手 1 )、 7 年目 (若 手 2 )、6 年目（若手 3 ）である。

\section{MIS手術の流れ}

ロボット支援下手術、腹腔鏡下手術とも全例、 全身麻酔下、砕石位で行い、膀胱バルーン（カフ 内蒸留水 $10 \mathrm{ml}$ ) で留置した。ロボット支援下手 術では頭低位15-23度で行い、右尾側からサイド ドッキングで手術を行った。腹腔鏡下手術では手 術台の性能上、正確な頭低位の角度は把握できて いないが、小腸が挙上されていくことを目安とし、 およそ20度前後の頭低位とした。マニピュレータ 一はルミIIコルポトマイザーシステム ${ }^{\circledR} を$ 使用し た。原則、子宮内膜増殖症や子宮内膜癌を疑う症 例にはマニピュレーターは使用しなかった。その 他、頸管狭窄などの理由でマニピュレーターの挿 入が困難な症例も $1 \sim 2$ 割存在した。平均気腹圧 はいずれも $8 \sim 10 \mathrm{mmHg}$ で維持した。

ロボット支援下手術では臍高レベルに 4 つの 8 $\mathrm{mm}$ 径の robotic working portを腹壁に設置し、 第1アームから第 4アームまでをドッキングした (図 1)。ポートの間隔は7.0〜 8.0 cmを基本とし、 ロボットアームが干渉しないよう体型に応じて適 宜調整した。第 1 アームの左側に $12 \mathrm{~mm}$ の assist portを留置し、助手操作や糸針、ガーゼの出し入 れなどに使用した。第1アームにフェネストレイ テッドバイポーラーフォーセプス、第 2 アームに 0 度カメラを使用した。導入時は第 3 アームにモ ノポーラーカーブドシザーズとメガニードルドラ イバーを使用していたが、32症例目より、モノポ ーラーの代わりに把持鉗子の役割も有するメリー ランドバイポーラーフォーセプスへ変更し、バイ ポーラーのスパークを利用して先端で組織を切離 するDouble Bipolar Methodを導入した。メリー ランドバイポーラーフォーセプスにForce Triad ${ }^{\circledR}$ のバイポーラーを接続し、「Macro mode 60W」 に設定することで使用可能である。da Vinci Xi ${ }^{\circledR}$ 


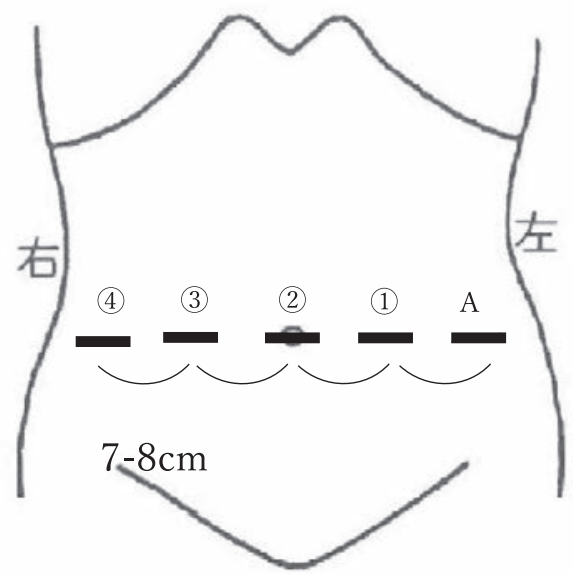

(1) 第 1 ポート

(2) 第 2 ポート

(3) 第 3 ポート

(4) 第 4 ポート

A アシストポート

図 1 ロボット支援下手術のポート配置

(1) (4)に8mm径のrobotic working port、Aに12mmアシストポートを留置した。

Surgical SystemではP8システムで直接コンソー ルに接続することができ、 surgeon console内の フットペダルで出力が可能である ${ }^{9)}$ 。導入初期は 第 4 アームにベッセルシーラーとカディエールフ オーセプスの両方を使用していたが、コストパフ ォーマンスの点から早期にカディエールフォーセ プスのみの使用に変更した。

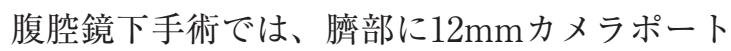
を留置し、左下腹部と下腹部正中に $5 \mathrm{~mm}$ ポート、 右下腹部に $10 \mathrm{~mm}$ ポートを留置し、ダイヤモンド 配置とした（図 2)。パワーデバイスは吸引管付 きモノポーラー、バイクランプ®、ソノサージま たはリガシュア ${ }^{\circledR}$ 使用した。

単純子宮全摘術の手術手順

手術手順はロボット支援下手術と腹腔鏡下手術 で大きな差異はない。まずは側方または後方アプ ローチで子宮動脈との交差部まで尿管を明らかに し、尿管と広間膜後葉の間の腔を展開する。円勒 帯を切断後、膀胱子宮窝腹膜を切開し、腟切断ラ インよりも尾側まで膀胱を十分に剥離する。ダグ ラス窩腹膜を切開した後に仙骨子宮勒帯を切断 し、卵巣固有勒帯または骨盤漏斗勒帯を切断する。 子宮動脈上行枝を集簇結禁、切断し、腟切断ライ ンまで可及的に処理しておく。腟円蓋に留置して いるカップを目印に腟壁を全周性に切開し、腟式 に子宮を摘出する。腟断端を吸収糸で1層縫合し、 生理食塩水で洗浄後、後腹膜を吸収糸で1層縫合 し、縫合部や腹膜欠損部に癒着防止シートを貼付 している。

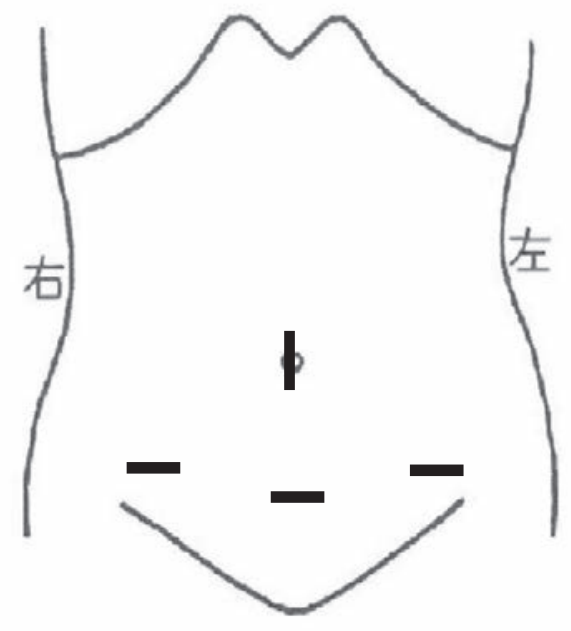

図 2 腹腔鏡下手術のポート配置

臍部に $12 \mathrm{~mm}$ カメラポートを、右下腹部に $10 \mathrm{~mm}$ ポート、左下 腹部と下腹部正中に $5 \mathrm{~mm}$ ポートを留置した。

検討項目と統計的手法

患者背景として、症例内訳、年齢、BMI、子宮 重量、マニピュレーター使用の有無、ダグラス窩 閉鎖を伴う内膜症性癒着の有無を評価した。また、 周術期アウトカムとして、手術時間、出血量、合 併症（腸管 - 尿路損傷、大量出血、術後発熱 - 感 染)の有無を評価した。

手術時間はポート創切開〜ポート創閉創（skin to skin time）と定義した。ロボット支援下手術 においては手術時間にドッキング時間（ロールイ ン開始〜コンソール開始）を含んでいる。

患者背景、周術期アウトカムともロボット支援 下手術群と腹腔鏡下手術群を、正規分布を示す連 続変数に対しては土検定を、それ以外には Wilcoxon rank sum検定（Mann-Whitney U検定） 
を用いて検定し、カテゴリー変数に対しては Fisher's正確確率検定を用いて統計解析を行っ た。有意水準を $\mathrm{p}$ 值 0.05 とし、統計ソフトはJMP ${ }^{\circledR}$ （ver 14.2）を使用した。

\section{結果}

ロボット支援下手術と腹腔鏡下手術の症例内訳 （表 1 ）は子宮筋腫19例（50\%）vs 11（39\%)、子 宮腺筋症 - 内膜症 2 例（ $5 \%$ ）vs 8 例 (29\%)、 CIN14例 (37\%) vs 8 例 (29\%)、子宮内膜増殖症内膜癌 3 例 $(8 \%)$ vs 1 例（3\%）であった。患 者背景（表 2 ）は、ロボット支援下手術と腹腔鏡 下手術で比較し、年齢の平均值は 47 vs 49 歳（p =0.62)、BMIの平均値は $23.4 \mathrm{vs} 22.9 \mathrm{~kg} / \mathrm{m}^{2}$ ( $\mathrm{p}=$ 0.57 )、子宮重量の中央值は 152 vs $175 \mathrm{~g} （ \mathrm{p}=$
0.39)、マニピュレーター使用は 28 例（73\%）vs 21例（75\%）（ $\mathrm{p}=0.90 ）$ と 2 群で差がなかったが、 ダグラス窩閉鎖を伴う内膜症性癒着は 0 例 ( $0 \%)$ vs 4 例（14\%）（ $\mathrm{p}=0.028 ）$ と腹腔鏡下手術で有 意に高頻度であった。

周術期アウトカムに関しては表 3 に示した。手 術時間の平均值は146 vs 175分（p=0.048）で、 ロボット支援下手術では腹腔鏡下手術と比較して 有意に短かった（図 3 )。ロボット支援下手術で のドッキング時間の平均值は $8 \pm 3$ 分で、コンソ ール時間の平均值は $122 \pm 41$ 分であった。ダグラ 不窩閉鎖を伴う内膜症性癒着の症例 4 例を除外儿 た場合の腹腔鏡下手術の平均值は 172 分で、ロボ ット支援下手術よりも長い傾向にはあったが有意 差は認めなかった。術者別にロボット支援下手術

\begin{tabular}{|c|c|c|c|c|}
\multicolumn{1}{c|}{ 表 1 症例内訳 } \\
\hline \multicolumn{1}{|c|}{} & \multicolumn{2}{|c|}{ ロボット支援下手術 } & \multicolumn{2}{|c|}{ 腹腔鏡手術 } \\
\cline { 2 - 5 } & \multicolumn{2}{|c|}{$(\mathrm{n}=38)$} & \multicolumn{2}{|c|}{$(\mathrm{n}=28)$} \\
\cline { 2 - 5 } & 症例数 & 割合 & 症例数 & 割合 \\
\hline \hline 子宮筋腫 & 19 & $50 \%$ & 11 & $39 \%$ \\
\hline 子宮腺筇症・内膜症 & 2 & $5 \%$ & 8 & $29 \%$ \\
\hline $\mathrm{CIN}$ & 14 & $37 \%$ & 8 & $29 \%$ \\
\hline 子宮内膜增殖症・内膜癌 & 3 & $8 \%$ & 1 & $3 \%$ \\
\hline
\end{tabular}

表2 患者背景

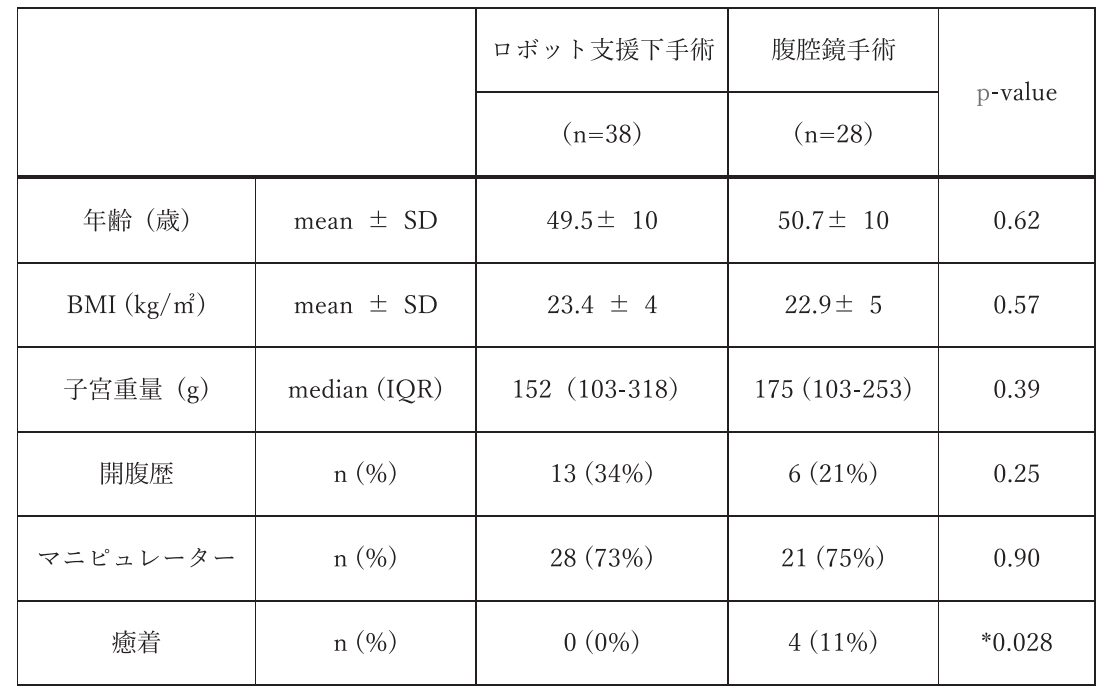

注）癒着 : ダグラス窩閉鎖を伴う内膜症性癒着 
と腹腔鏡下手術の手術時間を検討したところ、表 4 のような結果となり、4 名のうち 2 名の術者は ロボット支援下手術の方が手術時間は有意に短か く(表 4)、ロボット支援下手術は経時的に手術 時間が短縮していく傾向にあり（図 4 ）、腹腔鏡 下手術では経時的に手術時間が短縮する傾向はそ しかった（図 5 )。

出血量の中央值は 5 vs $23 \mathrm{~g}(\mathrm{p}=0.77)$ であり、 両群間での有意差は認めなかったが、ロボット支 援下手術群で少ない傾向にあった（図 6)。

周術期合併症は両群で腟断端感染に起因すると 思われる術後発熱を認め、ロボット支援下手術群 で 5 例、腹腔鏡下手術群で 3 例認めた。いずれも 1 週間程度の抗菌薬投与で解熱、治癒した。その 他、腸管・尿路損傷や輸血を要する大量出血など の重篤な合併症は認めなかった。

\section{考察}

本検討では、ロボット支援下手術と腹腔鏡下手 術での単純子宮全摘術における周術期アウトカム を後方視的に比較検討した。

子宮全摘術において、500例ほどの腹腔鏡下手 術と30例以上のロボット支援下手術の経験を有す
る 2 名の術者の報告 ${ }^{2}$ では、腹腔鏡下手術の平均 手術時間は $75 \pm 21$ 分でロボット支援下手術の 106 \pm 29 分よりも有意に短く、75～400例の腹腔鏡下 手術と20例以上のロボット支援下手術の経験を有 する 5 名の術者の報告 ${ }^{3)}$ では腹腔鏡下手術の平均 手術時間は $103 \pm 64$ 分でロボット支援下手術の 173 土89分よりも有意に短く、腹腔鏡下手術に十分に 習熟している術者の場合は腹腔鏡下手術の方が手 術時間が短いとされている。一方で、術者要件の 明記はないが、習熟した術者による腹腔鏡下手術 の手術時間が中央值104分でロボット支援下手術 の76分よりも長い傾向にあったという報告 ${ }^{4)}$ も存 在する。

当院では技術認定医 1 名と専門医取得後の技術 認定医を目指している若手医師 3 名の計 4 名での チーム構成であり、若手医師はロボット支援下手 術の術者要件を満たしているものの腹腔鏡下手術 の修練過程であった。当院での腹腔鏡下手術はこ れらの既報と比較して手術時間が長かったが、術 者の腹腔鏡下手術の習熟度の違いによるものと考 えられた。今回の検討ではロボット支援下手術の 手術時間が有意に短く、まだ腹腔鏡下手術に時間 を要する若手医師においても、ロボット支援下手

表 3 周術期アウトカム

\begin{tabular}{|c|c|c|c|c|}
\hline \multicolumn{2}{|c|}{} & \begin{tabular}{c} 
ロボット支援下手術 \\
\cline { 2 - 3 }
\end{tabular} & 腹腔鏡手術 & \multirow{2}{*}{ p-value } \\
\cline { 3 - 4 }$(\mathrm{n}=38)$ & $(\mathrm{n}=28)$ & \\
\hline 手術時間 (分) & mean $\pm \mathrm{SD}$ & $146 \pm 44$ & $175 \pm 50$ & $* 0.048$ \\
\hline 出血量 (g) & median (IQR) & $5(0-53)$ & $23(0-50)$ & 0.77 \\
\hline 合併症 (例) & (症例数(\%)) & $5(13 \%)$ & $3(11 \%)$ & 1.0 \\
\hline
\end{tabular}

表 4 術者別の手術時間の検討

\begin{tabular}{|c|c|c|c|c|c|}
\hline & \multicolumn{2}{|c|}{ ロボット支援下手術 } & \multicolumn{2}{|c|}{ 腹腔鏡下手術 } & \multirow{2}{*}{ p-value } \\
\cline { 2 - 5 } & $\mathrm{n}$ & 手術時間 (分) (mean \pm SD) & $\mathrm{n}$ & 手術時間 (分) (mean \pm SD) & \\
\hline \hline 指導医 & 4 & $166 \pm 16$ & 2 & $234 \pm 19$ & $* 20.048$ \\
\hline 若手 1 & 15 & $130 \pm 7$ & 10 & $158 \pm 10$ & $* 0.035$ \\
\hline 若手 2 & 10 & $178 \pm 10$ & 15 & $173 \pm 8$ & 0.69 \\
\hline 若手 3 & 9 & $179 \pm 23$ & 4 & $233 \pm 35$ & 0.23 \\
\hline
\end{tabular}


術では手術時間が短縮する可能性が示唆された。 ロボット支援下手術はlearning curveが早いこと も特徴のひとつである ${ }^{6,7)}$ 。ロボット支援下手術で は腹腔鏡下手術と比較し、鉗子の操作性が良く従

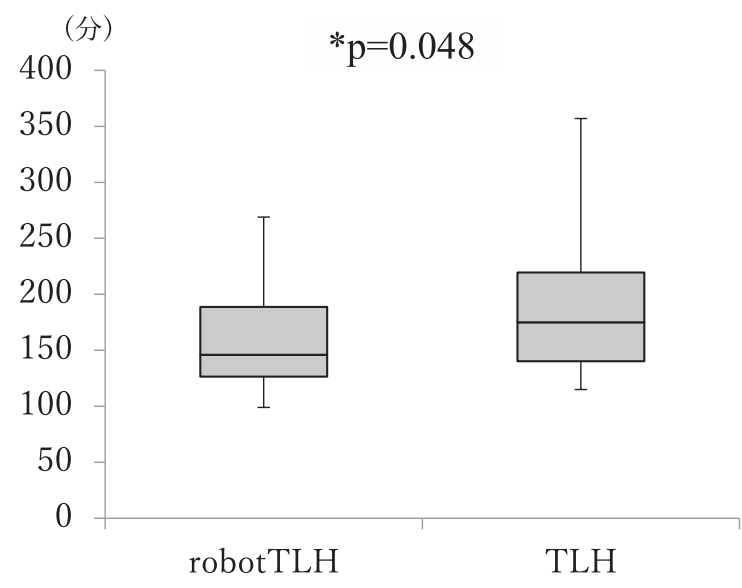

図3ロロボット支援下手術と腹腔鏡下手術の手術時間の比較 ロボット支援下手術 (robot TLH) は腹腔鏡下手術 (TLH) より 手術時間が有意に短かった $\left({ }^{*} p=0.048\right)$ 。
来の手術操作に近い可動性の広い動きが可能とな るため、腹腔鏡下手術では困難である鉬子に対す る垂直方向の操作が可能であることや、鈍的、鋭 的剥離を素早く切り替えて行いやすいことが、手 術時間を短縮できた要因と考えられる。

ただし十分にロボット支援下手術を習熟するた めには50〜 100例の手術経験が必要で 10)、20例前 後で重篤な合併症を起こしやすい ${ }^{11)}$ と言われて おり、まだ細心の注意は必要である。

本検討での出血量は両群間で有意差は認めなか ったが、ロボット支援下手術で少ない傾向を認め た。ロボット支援下手術では最大10倍の拡大視野 での立体画像により緻密な操作が可能となるた め、一般的にも出血量が少なくなるという報告が 多くみられた

合併症については、術後発熱をロボット支援下 手術で 5 例と腹腔鏡下手術で 3 例認めた。臨床所 見上、いずれも胵断端感染が疑われたため、抗菌 薬を投与した。いずれの症例も数日で解熱、改善

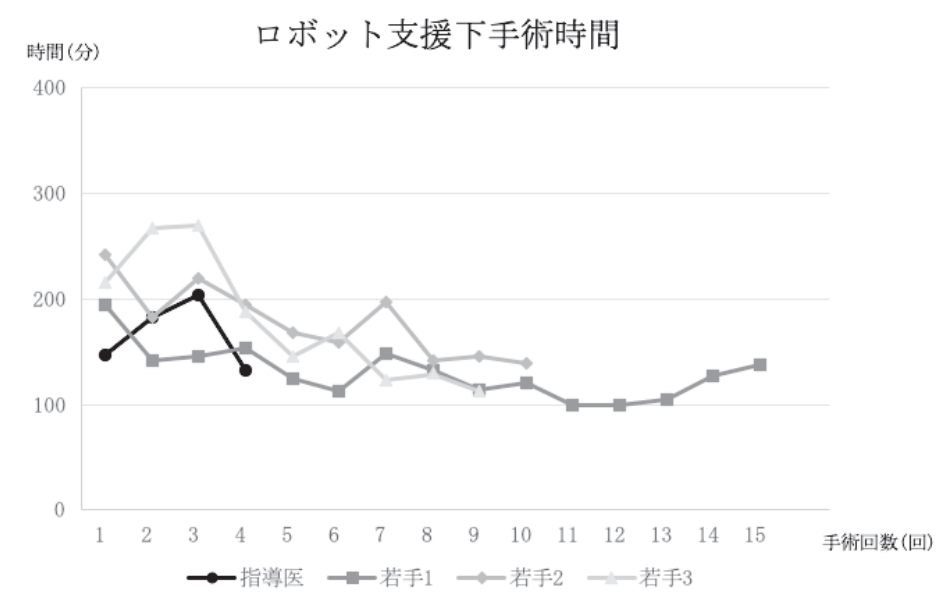

図 4 術者別のロボット支援下手術の手術時間

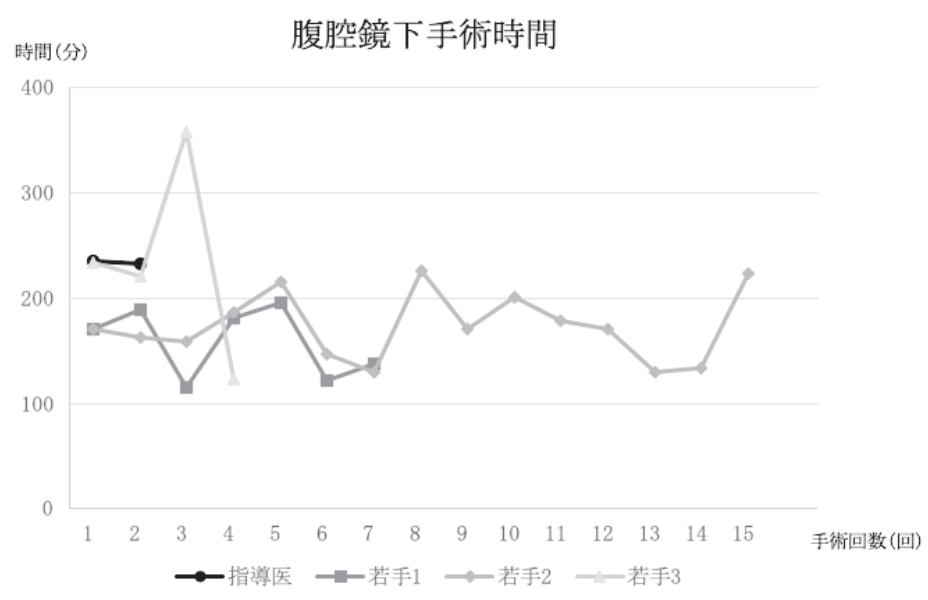

図 5 術者別の腹腔鏡下手術の手術時間 


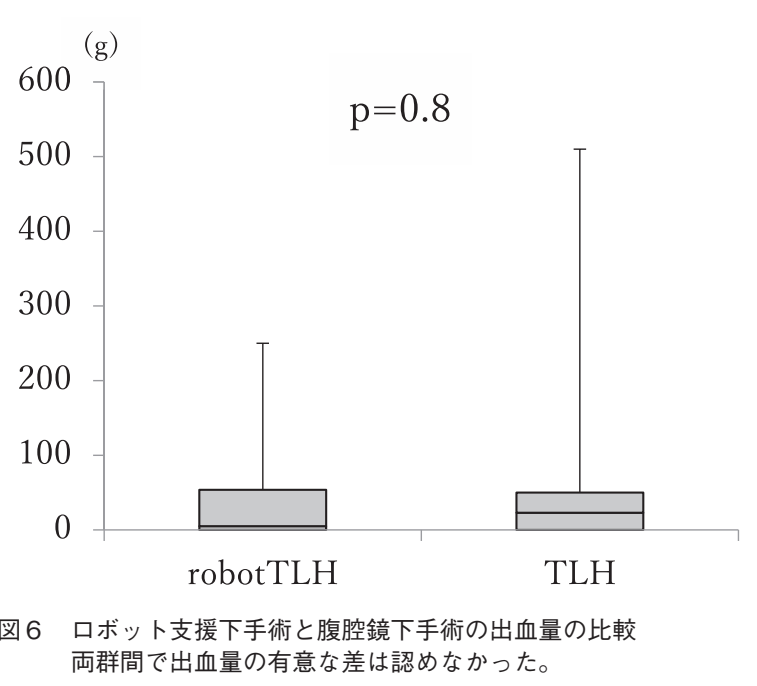

を得られた。他臟器損傷や大量出血、再手術など の重篤な合併症は認めなかった。一般的にも両群 間で合併症の有無に有意差がないとする報告が多 数みられた

ロボット支援下手術の利点としてlearning curveが早いことの他に、術者がコンソールに座 して手術が行えることから肩こり、腰痛など慢性 的な疲労の軽減になること、教育ツールとしてビ ジョンカートを用いて手術画面上に直接マーキン グすることができるテレストレーション機能を用 いられることがある。実際に、指導医が切開ライ ンや尿管などの構造物の位置を術野外から術者に 正確に伝え、リアルタイムで視覚的に指導するこ とができる。ロボットの鉗子の操作性に、解剖学 的に具体的な指導が加わるため、特に若手医師に おいて指導医の経験やイメージをそのまま再現 し、指導医と同じような手術の流れが早期に取得 しやすいと考えられる。腹腔鏡下手術に比べコミ ユニケーションッールとしてロボット支援下手術 は非常に有用であったと実感する。導入時期から 少人数チームの全員が術者のcertificateを取得し たことで、短期間で多くの症例をチームで経験で き、ドッキング時間や手術時間の短縮につながっ たと考えている。

ロボット支援下手術の短所と課題として、各種 機材や消耗品などを含めるとコストが高いため、 必要に応じて適宜使用デバイスを節約している が、それでも10万円単位でコストが高いことが問 題点である。今後ライセンスアウトにより他社の 参入が見込まれるが、腹腔鏡下手術と同レベルあ るいはそれ以下のコストまでいかに下げることが できるかに期待が集まる。またロボット支援下手
術は鉗子の把持力が強いため、摘出する子宮の把 持の際に出血をきたしたり、大きな子宮や癒着症 例などで腸管や尿管などの把持が必要な場合に繊 細な操作が必要であり、視野外の操作は他臓器損 傷の危険が高く十分気をつけなければならない。 助手が視野を展開することは腹腔鏡下手術と比較 して少ないため、助手が手術の流れを先んじて読 むといった伝統的な手術教育の良さも失われてし まうとも感じられる。

ロボット支援下手術は鉗子の操作性、鮮明な視 野、教育ツールといった点で優れている。本研究 のlimitationとしては、腹腔鏡下手術の多くは口 ボット支援下手術を導入前に行われていること が、バイアスとなっている。当院では若手医師を 多く含むチームで構成されているため、腹腔鏡下 手術に関しても個々の習熟度に応じて安全性重視 で行っている段階であり、手術時間の短縮は技術 認定医取得を目指して技量を高めながら解決すべ き課題である。今後も安全なロボット支援下手術 を継続していくにあたっては、子宮重量の大きい 症例や内膜症性癒着を有する難症例はそれぞれの 習熟度に応じて導入していく必要がある。

\section{結 論}

当院ではロボット支援下手術は導入段階である が、事前に適切な症例を選択し、少人数チーム全 員が同時に術者certificateを取得し、短期間にコ ンスタントに症例を全員で経験しながら取り組ん だことで安全にロボット支援下手術を導入するこ とができた。

本論文の要旨は第 60 回日本産科婦人科内視鏡学 会学術講演会において発表した。

全ての著者は開示すべき利益相反はない。

\section{参考文献}

1) Reich H, et al.: Total laparoscopic hysterectomy. Gynaecol Endosc 1993; 2: 59-63.

2 ) Dimitri S, et al.: Robotic compared with conventional laparoscopic hysterectomy: a randomized controlled trial. Obstet Gynecol. 2012 Sep; 120(3): 604-611.

3) Marie Fidela RP, et al.: A randomized trial comparing conventional and robotically assisted total laparoscopic hysterectomy. Am J Obstet Gyneco. 2013 May; 208(5): 368.

4) Celine L, et al.: A randomized trial comparing vaginal and laparoscopic hysterectomy vs robot- 
assisted hysterectomy. J Minim Invasive Gynecol. 2015 Jan; 22(1): 78-86.

5 ) Benjamin BA, et al.: Robotic Versus Laparoscopic Hysterectomy for Benign Disease: A Systematic Review and Meta-Analysis of Randomized Trials. J Minim Invasive Gynecol. 2016 Jan; 23(1): 18-27.

6 ) The American College of Obstetricians and Gynecologists (ACOG), 2015 Mar; 125(3): 760-767.

7 ) ChandraV, et al.: A comparison of laparoscopic and robotic assisted suturing performance by experts and novices. Surgery 2010; 147: 830-839.

8 ) Sgarbura O, et al:: The decisive role of the patientside surgeon in robotic surgery. Surg Endosc 2010 Dec; 24(12): 3149-3155.

9 ) 宇山一郎：ロボット支援下幽門側胃切除D1+ -セット アップの基本から実際の手術手技のコツまで-, Fujita， s Text 2, 2019; 27-29.

10) Lenihan JP Jr, et al.: What is the learning curve for robotic assisted gynecologic surgery? J Minim Invasive Gynecol 2008; 15: 589-594.

11) Bell MC, et al.: Comparison of outcomes and cost for endometrial cancer staging via traditional laparotomy, standard laparoscopy and robotic techniques. Gynecol Oncol 2008 Dec; 111(3): 407-411.

12) Martinez-Maestre MA, et al.: Total laparoscopic hysterectomy with and without robotic assistance: a prospective controlled study. Surg Innov. 2014; 21 : 250-255.

13) W J van Weelden, et al: Perioperative surgical outcome of conventional and robot-assisted total laparoscopic hysterectomy. Gynecol Surg. 2017; 14(1): 5.

14) Thomas NP, et al.: A comparison of total laparoscopic hysterectomy to robotically assisted hysterectomy: surgical outcomes in a community practice. J Minim Invasive Gynecol. May-Jun 2008; 15(3): 286-291.

15) Eric BR, et al.: Comparison of Robotic and Laparoscopic Hysterectomy for Benign Gynecologic Disease. Obstet Gynecol. 2013 Oct; 122(4): 778-786.

投稿日：2020年 9 月 2 日

採択日：2020年11月 2 日 